\title{
EU-China Trade: Geography and Institutions from 2001 to 2015
}

Dimitrios Karkanis

University of Thessaly, Volos, Greece

\begin{abstract}
This paper applies a gravity model to assess the factors underlying trade between the European Union and China separately for the exports and imports from 2001 to 2015. The two models are estimated for the 28 European Union countries. A panel data analysis aims to capture the effect of time on trade flows in view of the dynamic process of economic integration in the EU and the global financial crisis. The results suggest that the insularity and landlocked nature of several European Union member states are beneficial for bilateral trade flows. The entry of the European countries into the European Union, their alignment under a common monetary policy in the Eurozone environment, and the subsequent gradual adoption of a common currency have brought a higher degree of interconnectivity between the member states and have also made a positive contribution to European Union-China bilateral trade expansion.
\end{abstract}

JEL classifications: F14, F15

Keywords: China, Economic Integration, Gravity Equation, Bilateral Trade

* Corresponding Author: Dimitrios Karkanis; LDSA Laboratory, University of Thessaly, Pedion Areos, 38334, Volos, Greece, Tel: +30-24210-74432, E-mail: dkarkanis@uth.gr. 


\section{Introduction}

Since its gradual opening to international trade in the late 1970s, China now participates in trade with almost all countries in the world. Given the EU's dynamic institutional form including Brexit, bilateral trade between China and the EU is worth studying. Also, the global financial crisis in 2008 2009 has already left a mark on international trade flows as Bussière et al. (2010) points to the increasing public awareness for the protectionist measures.

This paper is to estimate a gravity model for EU-China bilateral trade flows during the 2001 2015 period to capture the economic, geographical, and institutional factors underlying the recent trends in trade relationships between China and the EU28 ${ }^{1}$ member states.

The remainder of the paper is organized as follows. Section II discusses the background describing trade relations between the EU and China, including an illustration of the balance of power between China and the EU countries. Section III reviews the previous empirical findings. Section IV describes data and analyze the results. Section V discusses policy implications related to the empirical findings.

\section{Background}

The EU has been heavy merchandise importer from China - more than the extent to which China is relying on imports from the EU. At the level of individual countries, Germany has been China's most important trading partner. It is the main recipient of Chinese products and by far the leading exporter of goods to China. As expected, EU countries with high income per capita or a relatively large domestic market, such as the Netherlands, the United Kingdom, Italy, France, and Spain, are among the main recipients of Chinese exports (Figure 1). However, the upward trend in the export value of Chinese merchandise to the majority of the aforementioned countries seems to have

\footnotetext{
${ }^{1}$ The EU28 is the abbreviation of European Union (EU) which consists a group of 28 countries (Belgium, Bulgaria, Czech Republic, Denmark, Germany, Estonia, Ireland, Greece, Spain, France, Croatia, Italy, Cyprus, Latvia, Lithuania, Luxembourg, Hungary, Malta, Netherlands, Austria, Poland, Portugal, Romania, Slovenia, Slovakia, Finland, Sweden, United Kingdom).
} 
bent over time, particularly after the beginning of the global financial crisis. However, this does not seem to be the case for some of the eastern EU countries, such as Poland, Slovenia, the Czech Republic, and Slovakia, according to the latest bilateral trade data (2015). This discrepancy raises questions regarding the factors that may influence the orientation of Chinese exports to individual EU countries, among which the level of development, expressed as the level of income per capita, seems to play a key role.

China's accession to the WTO had an effect on the country's trade liberalization process. After approximately 15 years, the balance of power in terms of international trade between the EU and China has changed rapidly, characterized by a general decline of the EU's contribution to world trade from 37\% to about 31\% between 2005 and 2015 , along with the doubling of China's corresponding contribution from $5.5 \%$ to about $11 \%$ during the same period (Figure 2). China has been exporting products to the EU, rather than the opposite at least since the country's entry into the WTO. In this context, the introduction of the following gravity model aims to identify factors that could possibly help balance the export and import trade flows.

The future establishment of a Free Trade Agreement (FTA) between China and the EU is passing through bilateral negotiations for a Comprehensive Agreement on Investment (CAI), which started in 2012. These negotiations included discussions on a wide range of trade-related issues, such as the further improvement of market access for investors, the elimination of discrimination cases against companies, and a regulatory environment that would ensure transparency procedures and the mutual respect of intellectual property rights (CEPS 2016). 


\section{Figure 1. Total value of Chinese merchandise exports and imports}
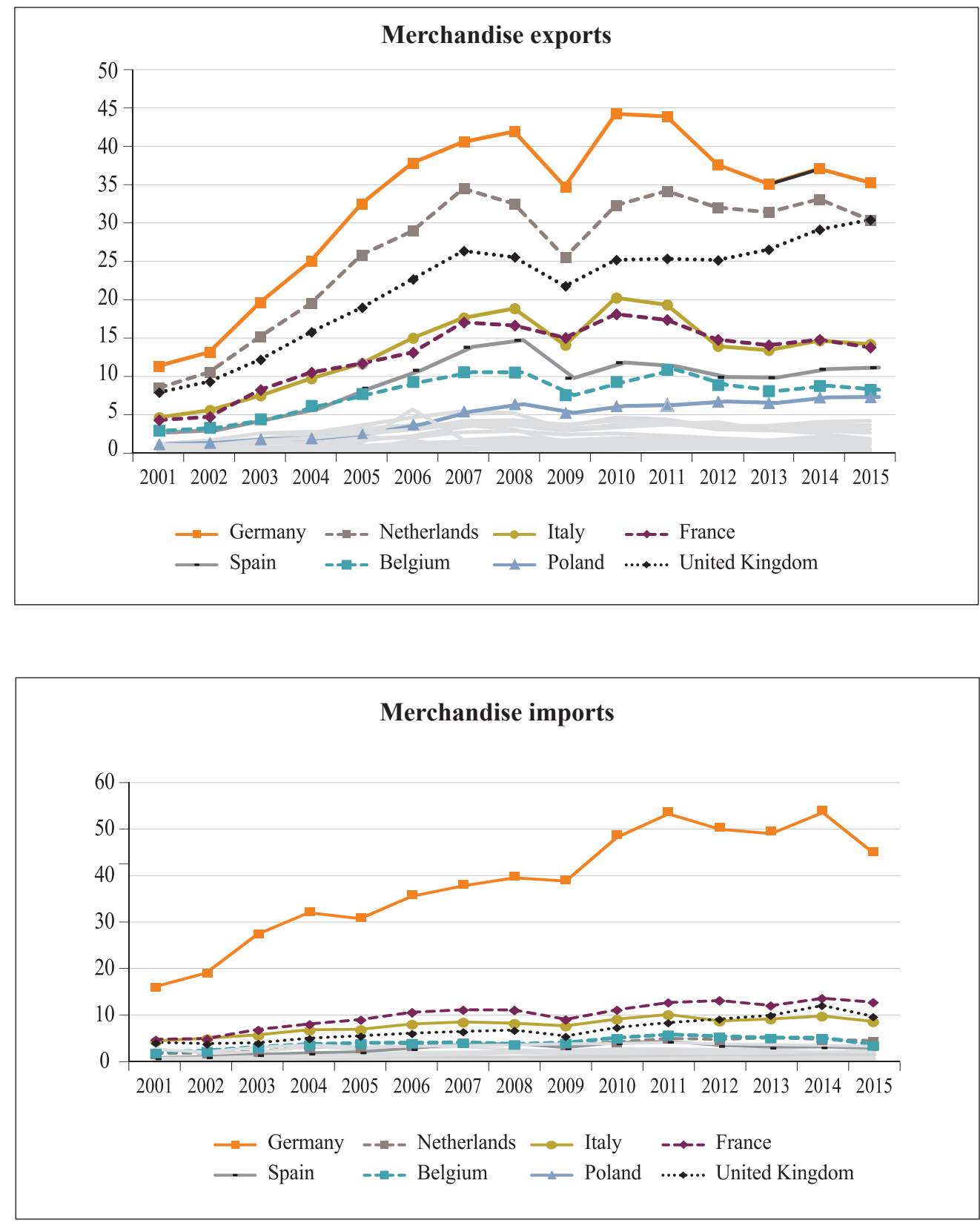

(Note) Estimated value of Chinese merchandise exports and imports by EU partner.

(Source) UNCTADstat online database (2017), values converted into 2005 billion constant dollars. 
Figure 2. Share of world trade in goods and services
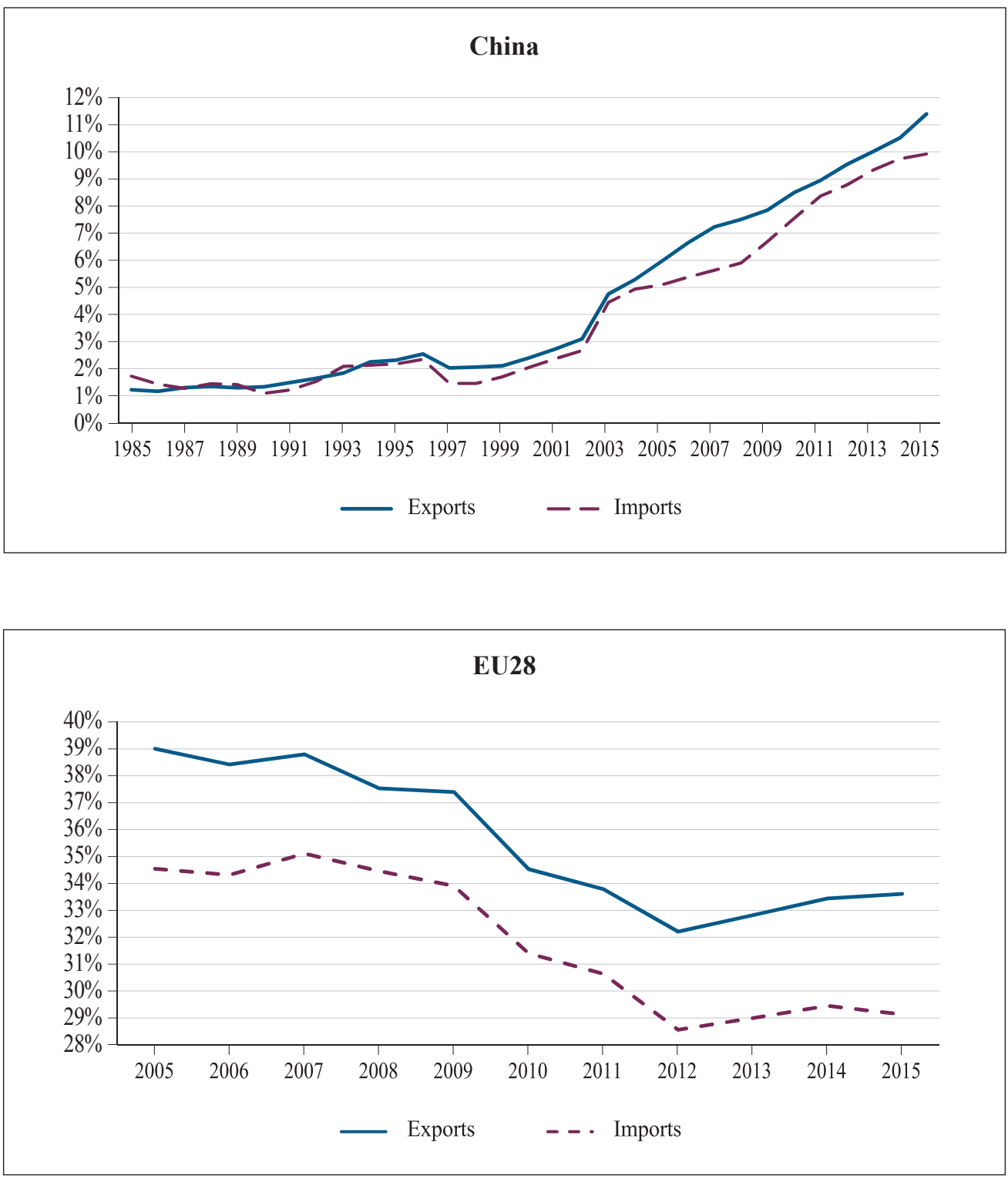

(Note) Chinese and EU28 trade of goods and services.

(Source) World Bank (2017) online database. 


\section{Literature Review}

A gravity equation in the context of international trade flow analysis was first applied by Tinbergen (1962) and Pöyhönen (1963). It is an analytical tool that is inspired by Newton's gravitational law and has been widely used by the international academic community. The first theoretical foundations of the gravity equation applied to trade flows are found in Anderson (1979), Helpman and Krugman (1985), and Bergstrand (1985). More recently, the empirical research has included various country-pair proxies in gravity equation modeling, such as geographical proxies, institutional proxies and historical and cultural proxies, among others.

The distance between trading partners traditionally reflects transportation costs in gravity models (Yu 2010) and Sheng et al. 2012). The estimated coefficients usually take a negative sign regarding the EU member states (Shepotylo 2010, Doumbe Doumbe and Belinga 2015, Zhang and Wang 2015, Caporale et al. 2015, and Didier and Koenig 2016).

The market size of a country is often represented by Gross Domestic Product (GDP). The estimates take a positive sign as shown in Linders and De Groot (2006) and Metulini et al. (2017). As an alternative, variable for market size, Kucera and Sarna (2006) chooses GDP per capita and population size. They also confirm a positive effect for GDP per capita and population size for both bilateral trade partners. Didier and Koenig (2016) obtains similar positive and statistically significant coefficients for the same variables China's trade with former-colonies which gained sovereignty between 1939 and 1999.

The empirical results suggest that being landlocked usually constitutes a resistance factor for bilateral trade flows (Kucera and Sarna 2006, Santos Silva and Tenreyro 2006, Felipe and Kumar 2010, Chen and Li 2014). To evaluate the impact of landlockedness on Central Asian trade, Grigoriou (2007) estimates a panel gravity equation for a sample of 167 countries during the 1992 2004 period. He mentions three factors indirectly associated with the Central Asian countries' infrastructures that play a key role in coping with the burden of being landlocked, which are the overland transportation costs, bargaining power, and infrastructure network, in relation to the involved transit countries. In the case of EU-China bilateral trade, Caporale et al. (2015) report a negative coefficient for bilateral trade between China and the EU27 member states during the 1992 2012 period, as well as for the more recent period between 2002 2012. The two estimated coefficients are statistically significant at the $10 \%$ level. Carmignani (2015) reports a statistically insignificant coefficient for landlocked countries in a gravity 
equation of the trade share in GDP, thus suggesting that institutional quality has a greater impact on transmitting the negative effect of being landlocked on the level of GDP per capita than does a country's international trade integration.

The empirical results suggest that the integration of European countries into the EU seems to be beneficial for their trade activities as reported by Martinez-Zarzoso and Nowak-Lehmann (2003) and Shepotylo (2010). However, the effects of WTO membership on trade seem rather ambiguous. Chang and Lee (2010) find a positive impact on bilateral trade between WTO members. Subramanian and Wei (2003) suggest a strong, positive, but also uneven, impact between industrial and developing countries while Eicher and Henn (2009) provides robust results supporting the absence of WTO effects. In the context of Chinese textile exports, Chan and $\mathrm{Au}$ (2007) reports a positive coefficient for the WTO dummy between China and its top-10 trading partners during the 1985 2004 period.

Studying bilateral trade between China and EU27 countries during the 2002 2012, Caporale et al. (2015) estimate a positive effect of the exporting country's size and WTO membership, along with a negative impact of geographical distance, landlockedness, and the global financial crisis on bilateral exports.

\section{Methodology and Results}

\section{A. Estimation model}

The estimated gravity models represent an augmented form of the basic gravity equation separately for Chinese imports and exports, in which trade value for each kind of flow is a log-linear function. The dummies are used to introduce the potential role of factors such as insularity, landlockedness, and the EU integration process toward the enhancement of bilateral trade growth. The gravity equations for Chinese exports and imports to and from the EU are expressed as follows, respectively:

$$
\begin{aligned}
& \ln X_{C i t}=\beta_{0}+\beta_{1} L n G D P p c_{i t}+\beta_{2} L n G D P_{C t}+\beta_{3} \operatorname{Ln}\left(P_{i t} \cdot P_{C t}\right)+\beta_{4} L n D_{C i} \\
& +\beta_{5} I S L_{i}+\beta_{6} E A N_{i t}+\sum_{t=3}^{11} \gamma_{t} T_{t}+\varepsilon_{C i}
\end{aligned}
$$




$$
\begin{aligned}
\ln M_{C i t}= & \beta_{0}^{\prime}+\beta_{1}^{\prime} L_{n} G D P p c_{i t}+\beta_{2}^{\prime} L n\left(P_{i t} \cdot P_{C t}\right)+\beta_{3}^{\prime} L_{n} D_{C i}+\beta_{4}^{\prime} I S L_{i}+\beta_{5}^{\prime} E A N_{i t} \\
& +\beta_{6}^{\prime} L L_{i}+\gamma_{1}^{\prime} T_{01}+\gamma_{2}^{\prime} T_{02}+\gamma_{3}^{\prime} T_{12}+\gamma_{4}^{\prime} T_{13}+\gamma_{5}^{\prime} T_{14}+\mathcal{E}_{C i}^{\prime}
\end{aligned}
$$

where $X_{C i t}$ denotes the value of China's merchandise exports to EU country $i$. And $M_{C i t}$ denotes the value of China's merchandise imports from EU country $i$ in year $t$. $P_{i t}$ and $P_{C t}$ are the respective population sizes for country $i$ and China in year $t$. GDPpcit is the GDP per capita of country $i$ in year $t$. GDP $C t$ is the Chinese GDP in year $t$ while $D_{C i}$ is the weighted distance between China and country $i$, according to CEPII's GeoDist database, which is appropriate for bilateral trade gravity models (CEPII 2011). The dummy variables, $I S L_{i}$ and $L L_{i}$, take the value 1 when corresponding to an island ${ }^{2}$ or a landlocked country $i$, respectively, otherwise they take the value 0 . The island explanatory variable can be considered to be an indicator for small-scale economies, while the landlockedness variable usually serves as a resistance factor for trade. The $E A N_{i t}$ variable denotes the number of Euro Area neighbors of a Euro Area country in year $t$, while taking the value 0 in the case of (i) island countries, (ii) non-Euro Area countries in year $t$, and (iii) Euro Area countries that do not border with other Euro Area countries in year $t$. $T$ is related to the time dimension, and it takes the value 1 exclusively for the corresponding year $t$, otherwise 0 . The terms $\varepsilon_{C i}$ and $\varepsilon_{C i}^{\prime}$ are the error terms.

The dataset covers bilateral trade flows between China and the 28 EU trading partners during the 2001 2015, recalling that the first year of observation coincides with China's accession to the WTO. Bilateral trade, GDP per capita, and population size are compiled by the UNCTAD Stat online database. The export-import values are deflated in 2005 constant dollars as this is already the case for GDP per capita values.

\section{B. Empirical results}

As expected, the distance variable has a significantly negative impact on export and import flows at the $1 \%$ level, but the magnitude of the coefficients in the two equations is different, suggesting that distance matters more for import flows.

\footnotetext{
${ }^{2}$ The United Kingdom is not considered to be an island country due to its road and commercial interconnection with the European hinterland via the Channel Tunnel.
} 
Demographic size, as an indicator of the market size, plays a significantly positive and role. It is not surprising that the effect of demographics is more important for imports than it is exports, given China's relatively larger population size. The transformation of the population variables into a single variable in the form of the product is to avoid collinearity issues with GDP and GDP per capita variables. The positive sign of the coefficient is consistent with the empirical results reported in the relevant literature.

Along with the population size variable, the variable related to the GDP of China is also an indicator for measuring market size effects on trade flows. This variable is excluded from the import equation to avoid collinearity effects. As for exports, the coefficient suggests an almost proportional change in export value along with GDP change as usually estimated for gravity models using GDP as an explanatory variable. The coefficient is statistically significant at the $1 \%$ level, and it is consistent with the literature (Santos Silva and Tenreyro 2006, Grigoriou 2007, Felipe and Kumar 2010, Caporale et al. 2015, Metulini et al. 2017).

The GDP per capita variable is a proxy that represents the income level and the purchasing power of exporter and importer countries as mentioned in Sohn (2005), reflecting the level of development of countries (Vlontzos and Duquenne 2008). The income variable is statistically significant at the $1 \%$ level and has the expected positive sign. 
Table 1. Results

(2001 2015)

\begin{tabular}{|c|c|c|}
\hline \multirow[t]{2}{*}{ Independent variables } & $\begin{array}{c}\text { Exports }-\mathrm{X}_{\mathrm{Cit}} \\
\text { (from China to } i \text { ) }\end{array}$ & $\begin{array}{c}\text { Imports - } \mathrm{M}_{\mathrm{Cit}} \\
\text { (from } i \text { to China) }\end{array}$ \\
\hline & $N=420$ & $N=414$ \\
\hline Constant & -36.704 & -10.987 \\
\hline Distance, $\operatorname{Ln}\left(D_{C i}\right)$ & $-0.960(-3.022)^{* * *}$ & $-2.472(-4.013)^{* * *}$ \\
\hline $\begin{array}{l}\text { Per capita GDP of EU country } i \text {, } \\
\operatorname{Ln}\left(G D P p c_{i t}\right)\end{array}$ & $0.794(19.934)^{* * *}$ & $1.222(18.480)^{* * *}$ \\
\hline GDP of China, $\operatorname{Ln}\left(G D P_{C t}\right)$ & $1.020(11.270)^{* * *}$ & \\
\hline Population size, $\operatorname{Ln}\left(P_{i t} \cdot P_{C t}\right)$ & $0.789(29.871)^{* * *}$ & $1.108(33.936)^{* * *}$ \\
\hline Island country $i, I S L_{i}$ & $0.418(3.129)^{* * *}$ & $1.510(4.810)^{* * *}$ \\
\hline Landlocked country $i, L L_{i}$ & - & $0.602(6.219)^{* * *}$ \\
\hline $\begin{array}{l}\text { Euro Area neighbors of } \\
\text { Euro Area country } i, E A N_{i t}\end{array}$ & $0.050(2.400)^{* *}$ & $0.169(6.593)^{* * *}$ \\
\hline$T_{2001}$ & - & $-0.789(-4.272)^{* * *}$ \\
\hline$T_{2002}$ & $\ldots$ & $-0.564(-3.063)^{* * *}$ \\
\hline$T_{2003}$ & $0.296(2.293)^{* *}$ & - \\
\hline$T_{2004}$ & $0.465(3.549)^{* * *}$ & - \\
\hline$T_{2005}$ & $0.599(4.769)^{* * *}$ & - \\
\hline$T_{2006}$ & $0.756(5.862)^{* * *}$ & $\therefore$ \\
\hline$T_{2007}$ & $0.704(6.706)^{* * *}$ & - \\
\hline$T_{2008}$ & $0.686(6.201)^{* * *}$ & - \\
\hline$T_{2009}$ & $0.342(2.777)^{* * *}$ & - \\
\hline$T_{2010}$ & $0.389(3.166)^{* * *}$ & - \\
\hline$T_{2011}$ & $0.335(2.692)^{* * *}$ & - \\
\hline$T_{2012}$ & - & $0.310(1.876)^{*}$ \\
\hline$T_{2013}$ & - & $0.316(1.863)^{*}$ \\
\hline$T_{2014}$ & - & $0.341(2.065)^{* *}$ \\
\hline$T_{2015}$ & - & - \\
\hline Adjusted $R^{2}$ & 0.838 & 0.806 \\
\hline F-test & $145.652^{* * *}$ & $157.299^{* * *}$ \\
\hline Durbin-Watson (d) & 1.995 & 1.958 \\
\hline
\end{tabular}

(Note) OLS estimations with White's heteroscedasticity-consistent covariance matrix estimator. The observations for Cyprus during the 2001 2006 period were excluded from the imports' equation. $t$ - Statistics are in parentheses. The superscript $* * *$ means $\mathrm{p}<0.01, * * \mathrm{p}<0.05, * \mathrm{p}<0.1$. 
As for the two geographical dummies, insularity has a positive impact on trade flows. The sign is positive and statistically significant for both kinds of flows. The OLS estimation results reveal a relatively stronger impact in the case of Chinese imports. This is probably due to the fact that island countries are generally characterized by smallersized markets, which result in a weaker positive impact for their imports when compared with export flows to China. In addition, island countries are generally urged to strengthen export activities to boost economic growth, given the limited margins of domestic market expansion. Nevertheless, the sign is positive and statistically significant for both kinds of flows. What is not very common is the positive sign for Chinese imports from landlocked countries (Austria, the Czech Republic, Hungary, Luxembourg, and Slovakia). One reasonable explanation of this positive impact for landlocked countries may be due to the compensation effect of the geographical proximity to China compared to Germany, France, Italy, and Poland). A positive externality of being at the crossroads of large markets, such as the Western Europe and China cannot be underestimated particularly when transportation network are established. With regard to Chinese exports toward the EU, the landlocked dummy coefficient is statistically insignificant and we exclude the dummy variable.

The behavior of the institutional and geographical dummy, $E A N_{i t}$, is as expected. The entry of an EU country into the common monetary policy environment and sharing a common border with as many other Euro Area countries as possible can facilitate trade flows to and from a third country, such as China. The elasticity for exports tends to be slightly lower than that for imports. The overall results suggest that there is still no disadvantage with landlockness as in the case of Austria that belongs to the Euro Asia.

The fifteen dummies denoting the dimension of time $\left(\mathrm{T}_{2001} \sim \mathrm{T}_{2015}\right)$ reveal mixed coefficient signs. In the field of exports, all dummies take a rather expected positive sign, reporting those that are statistically significant at the 1\% and 5\% levels (2003 2011). Their respective coefficients reveal the increasing importance of the time dimension but appears to have abruptly weakened from 2009 onward. This fact can be related to the global financial crisis and consequent slowdown of exports from China to the EU countries. From the import side, the statistically significant coefficients take negative signs for the first 2 years, which turn into positive signs during the 2012 2014 period. One possible explanation of the aforementioned results could be the positive aftereffect of China's accession to the WTO in 2001, which was not automatically evident for the first two years. The positive evolutions might be partially strengthened by joining the Eurozone system from 2007 onwards but weakened by the negative impact of the global financial crisis (2008 2009). 


\section{Conclusions}

The applied gravity model provided robust results on some of the determinants of EU-China bilateral trade flows during the 2001 2015. As expected, market size and income proxies are positively related to both export and import flows, simultaneously revealing a relatively stronger impact of the GDP per capita of the EU28 countries on Chinese imports rather than exports. Distance exerts a negative effect on trade, as commonly reported in the relevant literature.

The impact of the two time-invariant proxies is positive and statistically significant in both cases. In the case of EU countries, insularity also reveals a smaller market size with relatively limited expansion potential, thus imposing a relatively stronger positive effect on export flows to China rather than trade flows in the reverse direction. This finding is mainly due to the case of Ireland, which has succeeded in reversing the negative bilateral trade balance to a positive one since the beginning of the global financial crisis. As for the other two EU island countries, namely, Malta and Cyprus, they are highly dependent on tourism. The limited range of domestically produced goods in these two countries, combined with their limited human and natural resources, exert more pressure on import

Instead of acting as a resistance factor, landlockedness seems in this study to unleash its own positive externalities, implying a favorable infrastructure and transportation network for EU exports to China. The latest developments regarding the first direct freight train arrival from Xi'an in China to Budapest in Hungary on April 21, 2017, carrying 41 shipping containers over a 17 day trip (Daily News Hungary 2017), could possibly lead to similar findings in future analyses on EU-China bilateral trade as the landlocked European countries will be the first to be favored by this new freight transportation alternative. However, no major changes are expected in the near future as maritime transport remains by far the most cost-efficient way of freight transport.

In the sense that the EU is still open to the possibility of expanding to the East EUChina trade may expand. Apart from this geographical consideration, common monetary policy environments provided by the Eurozone will contribute to the trade of China and the EU, even if the future of the EU is to be assessed in the future.

Received 11 August 2017, Revised 29 January 2018, Accepted 14 February 2018 


\section{References}

Anderson, James E., A Theoretical Foundation for the Gravity Equation, The American Economic Review 69(1) (1979): 106-116.

Bergstrand, Jeffrey H., The Gravity Equation in International Trade: Some Microeconomic Foundations and Empirical Evidence, Review of Economics and Statistics 67(3) (1985): 474-481.

Bussière, Matthieu, Pérez-Barreiro, Emilia, Straub, Roland and Taglioni, Daria, Protectionist Responses to the Crisis. Global Trends and Implications, European Central Bank Occasional Paper Series 110 (2010).

Caporale, Guglielmo M., Sova, Anamaria and Sova, Robert, Trade flows and trade specialization: The case of China, China Economic Review 34 (2015): 261-273.

Carmignani, Fabrizio, The Curse of Being landlocked: Institutions Rather than Trade, The World Economy, DOI: 10.1111/twec.12248 (2015).

Centre for European Policy Studies (CEPS), Tomorrow's Silk Road: Assessing an EU-China Free Trade Agreement, Executive summary of the study conducted by the Centre of European Policy Studies (2016).

CEPII GeoDist database, data available at: http://www.cepii.fr/ (2017).

Chan, Eve M.H. and Au, K.F., Determinants of China's textile exports: An analysis by gravity model, The Journal of The Textile Institute 98(5) (2007): 463-469, DOI: 10.1080/00405000701556095.

Chang, Pao L. and Lee, Myoung J., 2011, The WTO trade effect, Journal of International Economics 85 (2007): 53-71. 
Chen, Bo and Li, Yao, Analyzing Bilateral Trade Barriers under Global Trade Context: A Gravity Model Adjusted Trade Intensity Index Approach, Review of Development Economics 18(2) (2014): 326-339, DOI:10.1111/rode.12087.

Didier, Laurent and Koenig, Pamina, Has China Replaced Colonial Trade? PSE Working Papers 23. <halshs-01397801> (2016).

Doumbe Doumbe, Eric and Belinga, Thierry, A Gravity Model Analysis for Trade between Cameroon and Twenty-Eight European Union Countries, Open Journal of Social Sciences 3 (2015): 114-122. http://dx.doi.org/10.4236/jss.2015.38013.

Eicher, Theo S. and Henn, Christian, In Search of WTO Trade Effects: Preferential Trade Agreements Promote Trade Strongly, but Unevenly, IMF Working Paper, WP/09/31 (2009).

Felipe, Jesus and Kumar, Utsav, The Role of Trade Facilitation in Central Asia: A Gravity Model, Levy Economics Institute of Bard College Working Paper (2010).

"First direct freight train from China arrives in Hungary", Daily News Hungary-MTI, posted by Daily News Hungary on April 21, 2017, accessed July 21, 2017, https:// dailynewshungary.com/first-direct-freight-train-china-arrives-hungary/

Grigoriou, Christopher, Landlockedness, Infrastructure and Trade: New Estimates for Central Asian Countries, The World Bank, Development Research Group, Trade Team, Policy Research Working Paper 4335 (2007).

Helpman, Elhanan, and Krugman, Paul. Market structure and foreign trade. Increasing returns, imperfect competition, and the international economy, Cambridge, MA: MIT Press (1985).

Kang, Joong S. and Liao, Wei, Chinese Imports: What's Behind the Slowdown?, IMF Working Paper WP/16/106, International Monetary Fund (2016). 
Kucera, David and Sarna, Ritash, Trade Union Rights, Democracy, and Exports: a Gravity Model Approach, Review of International Economics 14(5) (2006): 859-882. DOI:10.1111/j.1467-9396.2006.00627.x.

Linders, Gert J.M. and De Groot, Henri L.F., Estimation of the Gravity Equation in the Presence of Zero Flows, Tinbergen Institute Discussion Paper TI 2006-072/3, http:// www.tinbergen.nl/discussionpaper/?paper=788 (2006).

Lardy, Nicholas R. "Reality Check on China." In: Reality Check for the Global Economy, 16-18, edited by Olivier Blanchard and Adam S. Posen, Peterson Institute for International Economics, PIIE Briefing 16(3), (2016).

Martinez-Zarzoso, Inmaculada and Nowak-Lehmann, Felicitas, Augmented Gravity Model: An Empirical Application to Mercosur-European Union Trade Flows, Journal of Applied Economics 6(2) (2003): 291-316.

Mayer, Thierry and Zignago, Soledad, Notes on CEPII's distances measures: The GeoDist database, CEPII - Document de travail (2011): 2011-2025.

Metulini, Rodolfo, Riccaboni, Massimo, Sgrignoli, Paolo and Zhu, Zhen, The Indirect Effects of FDI on Trade: A Network Perspective, IMT Lucca EIC Working Paper Series 04 (2017).

Pöyhönen, Pentti, A Tentative Model for the Volume of Trade between Countries, Weltwirtschaftliches Archiv 90 (1963): 93-100.

Santos Silva, J.M.C. and Tenreyro, Silvana, The Log of Gravity, The Review of Economics and Statistics 88(4) (2006): 641-658.

Sheng, Yu, Tang, Hsiao C. and Xu, Xinpeng, The Impact of ACFTA on People's Republic of China-ASEAN Trade: Estimates Based on an Extended Gravity Model for Component Trade, ADB Working Paper Series on Regional Economic Integration 99 (2012). 
Shepotylo, Oleksandr, A Gravity Model of Net Benefits of EU Membership: The Case of Ukraine, Journal of Economic Integration 25(4) (2010): 676-702.

Sohn, Chan H., Does the Gravity Model Explain South Korea's Trade Flows?, The Japanese Economic Review 56(4) (2005): 417-430. DOI: 10.1111/j.14685876.2005.00338.x.

Subramanian, Arvind and Wei, Shang J., The WTO Promotes Trade, Strongly But Unevenly, IMF Working Paper WP/03/185 (2003).

Tinbergen, Jan. Shaping the World Economy: Suggestions for an International Economic Policy. New York: The Twentieth Century Fund, 1962.

UNCTADstat, United Nations Conference on Trade and Development online data center, data available at: http://unctadstat.unctad.org/ (2017).

Vlontzos, George and Duquenne, Marie N., Greek Olive Oil: How Can Its International Market Potential Be Realized? The Estey Centre Journal of International Law and Trade Policy 9(2) (2008): 125-140.

World Bank, 2016, The Impact of China on Europe and Central Asia, ECA Economic Update Spring 2016 (April), World Bank, Washington, DC. DOI: 10.1596/ 978-1-46480912-5, License: Creative Commons Attribution CC BY 3.0 IGO.

World Bank Open Data, 2017, data available at: http://data.worldbank.org/country.

Yu, Miaojie, Trade, democracy, and the gravity equation, Journal of Development Economics 91 (2010): 289-300.

Zhang, Yuqin and Wang, Shouyang, Trade Potential of China's Export to ASEAN: The Gravity Model Using New Economic Mass Proxies, Journal of Systems Science and Information 3(5) (2015): 411-420. 


\section{Appendices}

\section{Appendix 1: Definition and sources}

\begin{tabular}{|c|c|c|}
\hline Variable & Definition & Source \\
\hline Exports $\left(X_{C i t}\right)$ & $\begin{array}{c}\text { Chinese exports of goods to EU partner in } 2005 \\
\text { constant US dollars }\end{array}$ & $\begin{array}{l}\text { UNCTADstat (2017), values } \\
\text { converted in } 2005 \text { constant US } \\
\text { dollars by own calculations }\end{array}$ \\
\hline Imports $\left(M_{C i t}\right)$ & $\begin{array}{l}\text { Chinese imports of goods from EU partner in } \\
2005 \text { constant US dollars }\end{array}$ & $\begin{array}{l}\text { UNCTADstat (2017), values } \\
\text { converted in } 2005 \text { constant US } \\
\text { dollars by own calculations }\end{array}$ \\
\hline$D_{C i}$ & Distance from China to EU partner & $\begin{array}{l}\text { CEPII GeoDist database } \\
\text { (2017), distwces variable }\end{array}$ \\
\hline$G D P p c_{i t}$ & $\begin{array}{c}\text { Per capita GDP of EU partner in } 2005 \text { constant } \\
\text { US dollars }\end{array}$ & UNCTADstat (2017) \\
\hline$G D P_{C t}$ & GDP of China in 2005 constant US dollars & UNCTADstat (2017) \\
\hline $\boldsymbol{P}_{i t} \cdot \boldsymbol{P}_{C t}$ & $\begin{array}{l}\text { Product of population sizes of China and } \\
\text { EU partner }\end{array}$ & UNCTADstat (2017) \\
\hline$I S L_{i}$ & $\begin{array}{l}\text { Dummy variable for EU island countries, } \\
0 \text { or } 1 \text {, starting in } 2001\end{array}$ & Own calculations \\
\hline$L L_{i}$ & $\begin{array}{l}\text { Dummy variable for EU landlocked countries, } \\
\qquad 0 \text { or } 1 \text {, starting in } 2001\end{array}$ & Own calculations \\
\hline$E A N_{i t}$ & $\begin{array}{l}\text { Dummy variable for the number of Euro Area } \\
\text { neighbors of a Euro Area country, } 0 \text { to } 5 \text {, } \\
\text { starting in various years }\end{array}$ & $\begin{array}{l}\text { Official website of the } \\
\text { European Union and own } \\
\text { calculations }\end{array}$ \\
\hline$T_{2001} \sim T_{2015}$ & $\begin{array}{l}\text { Time dummies, value } 1 \text { for the observation } \\
\text { year, otherwise } 0\end{array}$ & Own calculations \\
\hline
\end{tabular}




\section{Appendix 2: OLS results}

\begin{tabular}{|c|c|c|c|c|}
\hline \multirow[b]{2}{*}{ Beta coefficients } & \multicolumn{2}{|c|}{$X_{\text {Cit }}$} & \multicolumn{2}{|c|}{$M_{\text {Cit }}$} \\
\hline & $\begin{array}{c}\text { Beta } \\
\text { coefficient }\end{array}$ & $P$-value & $\begin{array}{c}\text { Beta } \\
\text { coefficient }\end{array}$ & $P$-value \\
\hline Constant & 0.000 & 0.000 & 0.000 & 0.028 \\
\hline Distance, $\operatorname{Ln}\left(D_{C_{i}}\right)$ & -0.061 & 0.003 & -0.114 & 0.000 \\
\hline $\begin{array}{l}\text { Per capita GDP of EU country } i \\
\operatorname{Ln}\left(G D P p c_{i t}\right)\end{array}$ & 0.399 & 0.000 & 0.451 & 0.000 \\
\hline GDP of China, $\operatorname{Ln}\left(G D P_{C t}\right)$ & 0.283 & 0.000 & - & - \\
\hline Population size, $\operatorname{Ln}\left(P_{i t} \cdot P_{C t}\right)$ & 0.741 & 0.000 & 0.749 & 0.000 \\
\hline Island country $i, I S L_{i}$ & 0.086 & 0.002 & 0.213 & 0.000 \\
\hline Landlocked country $i, L L_{i}$ & - & - & 0.112 & 0.000 \\
\hline $\begin{array}{l}\text { Euro Area neighbors of Euro Area } \\
\text { country } i, E A N_{i t}\end{array}$ & 0.054 & 0.017 & 0.132 & 0.000 \\
\hline Dummy for $\mathrm{T}_{2001}$ & - & - & -0.094 & 0.000 \\
\hline Dummy for $\mathrm{T}_{2002}$ & - & - & -0.067 & 0.002 \\
\hline Dummy for $\mathrm{T}_{2003}$ & 0.049 & 0.022 & - & - \\
\hline Dummy for $\mathrm{T}_{2004}$ & 0.077 & 0.000 & - & - \\
\hline Dummy for $\mathrm{T}_{2005}$ & 0.099 & 0.000 & - & - \\
\hline Dummy for $T_{2006}$ & 0.125 & 0.000 & - & - \\
\hline Dummy for $\mathrm{T}_{2007}$ & 0.117 & 0.000 & - & - \\
\hline Dummy for $\mathrm{T}_{2008}$ & 0.114 & 0.000 & - & - \\
\hline Dummy for $\mathrm{T}_{2009}$ & 0.057 & 0.006 & - & - \\
\hline Dummy for $\mathrm{T}_{2010}$ & 0.064 & 0.002 & - & - \\
\hline Dummy for $T_{2011}$ & 0.056 & 0.007 & - & - \\
\hline Dummy for $\mathrm{T}_{2012}$ & - & - & 0.038 & 0.061 \\
\hline Dummy for $\mathrm{T}_{2013}$ & - & - & 0.038 & 0.063 \\
\hline Dummy for $\mathrm{T}_{2014}$ & $\therefore$ & - & 0.041 & 0.039 \\
\hline Dummy for $\mathrm{T}_{2015}$ & - & - & - & - \\
\hline
\end{tabular}

(Note) Estimations use White's heteroscedasticity-consistent covariance matrix estimator. 